\title{
STORE ATMOSPHERE DALAM MENCIPTAKAN EMOSI dan PENGARUHNYA TERHADAP KEPUTUSAN PEMBELIAN (Survey pada Pengunjung Alfamart, Jalan Soekarno Hatta, Ruko Center Point, Kota Malang)
}

\author{
Mochammad Lukman Zaini Kurniawan, Achmad Fauzi, Srikandi Kumadji \\ Fakultas Ilmu Administrasi, Universitas Brawijaya \\ Email: lukmanzaini@stt.ac.id
}

\begin{abstract}
The purpose this study to determine and explain whether there influence between Store Atmosphere, Emotion and Purchase Decision. This is causality research. Methods data collection using a survey. The population were all those people who have made purchases transaction in Alfamart minimarket, in Center Point. Sampling method using Non-Probability Sampling with questionnaires and analyzed using Partial Least Square. Results of this study are: 1) Store Exterior is significant to Purchasing Decision Structure, 2) Store Exterior is not significant to Pleasure, 3) Store Exterior is significant to Arousal, 4) Store Exterior is significant to Dominance, 5) Store Interior is significant to Pleasure, 6) Store Interior is significant to Arousal, 7) Store Interior is significant to Dominance, 8) Store Layout is not significant to Pleasure, 9) Store Layout is significant to Arousal, 10) Store Layout is significant to Dominance, 11) Interior Display of Store is significant to Pleasure, 12) Interior Display of Store is not significant to Arousal, 13) Interior Display of Store is significant to Dominance, 14) Interior Display of Store is significant to Purchasing Decision Structure, 15) Pleasure is significant to Purchasing Decision Structure, 16) Arousal is significant to Purchasing Decision Structure, 17) Dominance is significant to Purchasing Decision Structure.
\end{abstract}

Keywords : Store Atmosphere, Emotion, Purchasing Decision Structure.

\begin{abstract}
ABSTRAK
Tujuan penelitian adalah untuk mengetahui dan menjelaskan apakah ada pengaruh antara Suasana Toko, Emosi dan Keputusan Pembelian. Penelitian ini merupakan penelitian kausalitas. Metode pengumpulan data penelitian ini menggunakan metode survei. Populasi dalam penelitian ini adalah semua orang yang telah melakukan transaksi pembelian di minimarket Alfamart, ruko Center Point. Metode pengambilan sampel menggunakan Non Probability Sampling dengan menggunakan kuesioner dan analisis data menggunakan Partial Least Square. Hasil penelitian ini adalah : 1) Bagian Luar Toko signifikan terhadap Struktur Keputusan Membeli, 2) Bagian Luar Toko tidak signifikan terhadap Kesenangan, 3) Bagian Luar Toko signifikan terhadap Gairah, 4) Bagian Luar Toko signifikan terhadap Dominasi, 5) Bagian Dalam Toko signifikan terhadap Kesenangan, 6) Bagian Dalam Toko signifikan terhadap Gairah, 7) Bagian Dalam Toko signifikan terhadap Dominasi, 8) Tata Letak Toko tidak signifikan terhadap Kesenangan, 9) Tata Letak Toko signifikan terhadap Gairah, 10) Tata Letak Toko signifikan terhadap Dominasi, 11) Tampilan Bagian Dalam Toko signifikan terhadap Kesenangan, 12) Tampilan Bagian Dalam Toko tidak signifikan terhadap Gairah, 13) Tampilan Bagian Dalam Toko signifikan terhadap Dominasi, 14) Tampilan Bagian Dalam Toko signifikan terhadap Struktur Keputusan Membeli, 15) Kesenangan signifikan terhadap Struktur Keputusan Membeli, 16) Gairah signifikan terhadap Struktur Keputusan Membeli, 17) Dominasi signifikan terhadap Struktur Keputusan Membeli.
\end{abstract}

Kata Kunci : Store Atmosphere, Emosi, Struktur Keputusan Membeli. 


\section{PENDAHULUAN}

Di era Globalisasi persaingan antar perusahaan semakin ketat. Salah satu bidang usaha yang semakin kompetitif adalah bisnis ritel. Sejalan dengan perkembangan kebutuhan dan pola hidup masyarakat yang semakin menginginkan kenyamanan belanja, kepastian harga, dan keanekaragaman barang kebutuhan dalam satu toko, pelanggan menuntut pengusaha ritel dan toko untuk meningkatkan baik secara pengelolaan, penampilan toko, maupun cara pelayanan. Untuk itulah sejak sekitar tahun 2000-an mulai diperkenalkan convenience store, yaitu suatu toko yang beroperasi selama 24 jam. Kelebihan toko semacam itu adalah jaraknya yang dekat dengan pemukiman penduduk, bahkan bila perlu pelayannya mengenal para pelanggan. Komoditi yang dijual umumnya barang kebutuhan sehari-hari. Convenience store menyerupai toko kelontong, namun telah dilengkapi dengan prasarana yang lebih dari toko biasa, seperti pendingin ruangan, cashier machine, dan manajemen yang profesional.

Di Indonesia, convenience store secara umum disebut minimarket. Minimarket memiliki gerai yang lebih banyak jumlahnya jika dibandingkan dengan kelompok ritel lainnya seperti hypermarket dan supermarket. Hal ini didorong pula oleh kecenderungan bahwa gerai-gerai minimarket berada di lingkungan perumahan yang mudah dijangkau oleh konsumen. Gerai minimarket berkembang pesat karena didukung oleh sistem waralaba (franchise) seperti Indomaret dan Alfamart.

Store atmosphere, merupakan salah satu unsur pendukung Place dalam marketing mix. Store atmosphere yang menarik akan mempengaruhi tingkat keputusan konsumen untuk membeli pada sebuah toko. Store atmosphere yang kondusif, juga dapat mempengaruhi konsumen untuk melakukan pembelian di luar apa yang direncanakan (unplanned purchase). Suasana toko terdiri dari empat variabel yaitu : 1)Bagian Luar Toko, 2)Bagian Dalam Toko, 3)Tata Letak Toko dan 4)Tampilan Bagian Dalam Toko. Status Emosi seorang konsumen sangat berpengaruh terhadap Struktur Keputusan Membeli. Emosi seseorang terbagi dalam tiga variabel antara lain : Kesenangan (Pleasure), Gairah (Arousal), dan Dominasi (Dominance).

Berdasarkan uraian latar belakang, maka rumusan masalah dalam penelitian ini adalah:
1. Apakah variabel Bagian Luar Toko berpengaruh terhadap variabel Struktur Keputusan Membeli?

2. Apakah variabel Bagian Luar Toko berpengaruh terhadap variabel Kesenangan?

3. Apakah variabel Bagian Luar Toko berpengaruh terhadap variabel Gairah?

4. Apakah variabel Bagian Luar Toko berpengaruh terhadap variabel Dominasi?

5. Apakah variabel Bagian Dalam Toko berpengaruh terhadap variabel Kesenangan?

6. Apakah variabel Bagian Dalam Toko berpengaruh terhadap variabel Gairah?

7. Apakah variabel Bagian Dalam Toko berpengaruh terhadap variabel Dominasi?

8. Apakah variabel Tata Letak Toko berpengaruh terhadap variabel Kesenangan?

9. Apakah variabel Tata Letak Toko berpengaruh terhadap variabel Gairah?

10. Apakah variabel Tata Letak Toko berpengaruh terhadap variabel Dominasi?

11. Apakah variabel Tampilan Bagian Dalam Toko berpengaruh terhadap variabel Kesenangan?

12. Apakah variabel Tampilan Bagian Dalam Toko berpengaruh terhadap variabel Gairah?

13. Apakah variabel Tampilan Bagian Dalam Toko berpengaruh terhadap variabel Dominasi?

14. Apakah variabel Tampilan Bagian Dalam Toko berpengaruh terhadap Struktur Keputusan Membeli?

15. Apakah variabel Kesenangan berpengaruh terhadap variabel Struktur Keputusan Membeli?

16. Apakah variabel Gairah berpengaruh terhadap variabel Struktur Keputusan Membeli?

17. Apakah variabel Dominasi berpengaruh terhadap variabel Struktur Keputusan Membeli?

\section{LATAR BELAKANG TEORI DAN HIPOTESIS}

Bab ini terdiri dari dua bagian. Bagian pertama membahas kerangka dasar teoritis, yang meliputi : Suasana Toko (Store Atmosphere), Emosi, Keputusan Pembelian, Convenience Store dan SOR Models. Bagian kedua membahas penelitian terdahulu yang menjadi dasar empiris penelitian ini. 
Pada bab ini juga membahas dasar kerangka pemikiran yang digunakan dalam penelitian ini yaitu SOR (Stimulus Organism Response) Models. Model ini diperkenalkan oleh Mehrabian and Russell (1976) yang mengatakan bahwa semua tanggapan ke Stimuli Lingkungan (S) dapat diperlakukan sebagai suatu tanggapan Pendekatan (Approach) atau Penghindaran (Avoidance) ( $\mathrm{R})$, dengan pengalaman individu di dalam lingkungan $(\mathrm{O})$ sebagai mediator. Yang digambarkan sebagai berikut :

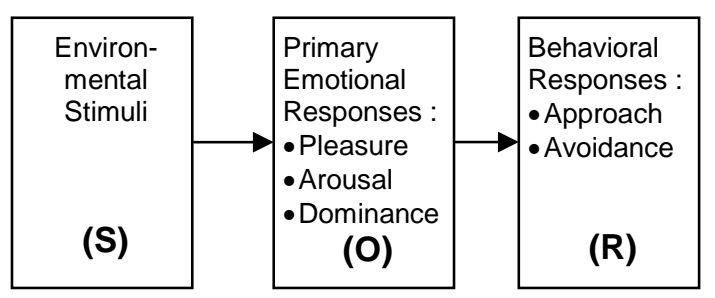

Gambar 1. SOR Models, sumber : Donovan Rossiter, 1982 h. 42 dalam Peter Olson, 2000 h. 251.

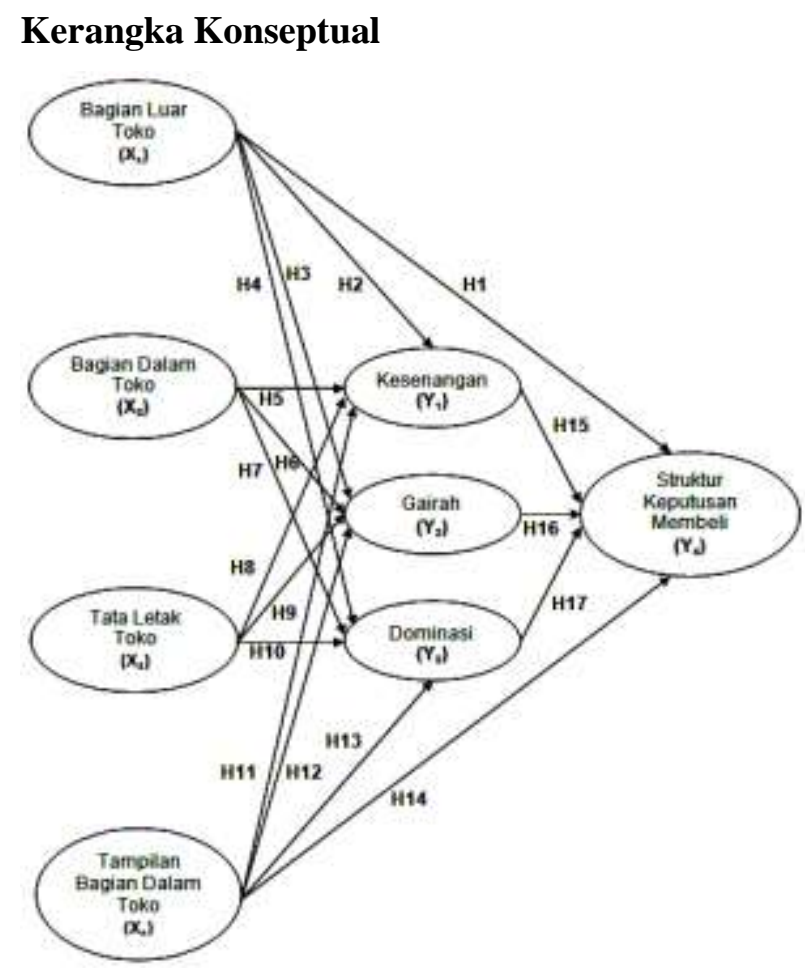

Gambar 2. Model Hipotesis

\section{Hipotesis Penelitian}

Tabel 1. Rumusan Hipotesis, Dasar Teoritis dan Penelitian Terdahulu

\begin{tabular}{|c|c|c|c|}
\hline No & Rumusan Hipotesis & $\begin{array}{l}\text { Dasar } \\
\text { Teoritis }\end{array}$ & $\begin{array}{l}\text { Penelitian } \\
\text { Terdahulu }\end{array}$ \\
\hline 1 & $\begin{array}{l}\text { Bagian Luar Toko } \\
\text { berpengaruh signifikan } \\
\text { terhadap Struktur } \\
\text { Keputusan Membeli }\end{array}$ & $\begin{array}{l}\text { Berman } \\
\text { and } \\
\text { Evans } \\
1994 \mathrm{p} .\end{array}$ & $\begin{array}{l}\text { Paul C.S. Wu } \\
\text { et al, (2011) }\end{array}$ \\
\hline 2 & $\begin{array}{l}\text { Bagian Luar Toko } \\
\text { berpengaruh signifikan } \\
\text { terhadap Kesenangan }\end{array}$ & $\begin{array}{l}\text { Berman } \\
\text { and } \\
\text { Evans } \\
1994 \mathrm{p} .\end{array}$ & $\begin{array}{l}\text { Young Ha et } \\
a l,(2011)\end{array}$ \\
\hline 3 & $\begin{array}{l}\text { Bagian Luar Toko } \\
\text { berpengaruh signifikan } \\
\text { terhadap Gairah }\end{array}$ & $\begin{array}{l}\text { Berman } \\
\text { and } \\
\text { Evans } \\
1994 \mathrm{p} .\end{array}$ & $\begin{array}{l}\text { Michel } \\
\text { Laroche, et al, } \\
(2005)\end{array}$ \\
\hline 4 & $\begin{array}{l}\text { Bagian Luar Toko } \\
\text { berpengaruh signifikan } \\
\text { terhadap Dominasi }\end{array}$ & $\begin{array}{l}\text { Berman } \\
\text { and } \\
\text { Evans } \\
1994 \mathrm{p} .\end{array}$ & $\begin{array}{l}\text { Elfriede Penz } \\
\text { et al, (2009) }\end{array}$ \\
\hline 5 & $\begin{array}{l}\text { Bagian Dalam Toko } \\
\text { berpengaruh signifikan } \\
\text { terhadap Kesenangan }\end{array}$ & $\begin{array}{l}\text { Berman } \\
\text { and } \\
\text { Evans } \\
1994 \mathrm{p} .\end{array}$ & $\begin{array}{l}\text { Sevgin A. } \\
\text { Eroglu et al, } \\
(2003)\end{array}$ \\
\hline 6 & $\begin{array}{l}\text { Bagian Dalam Toko } \\
\text { berpengaruh signifikan } \\
\text { terhadap Gairah }\end{array}$ & $\begin{array}{l}\text { Berman } \\
\text { and } \\
\text { Evans } \\
1994 \mathrm{p} .\end{array}$ & $\begin{array}{l}\text { Ingrid Y. Lin } \\
(2008)\end{array}$ \\
\hline 7 & $\begin{array}{l}\text { Bagian Dalam Toko } \\
\text { berpengaruh signifikan } \\
\text { terhadap Dominasi }\end{array}$ & $\begin{array}{l}\text { Berman } \\
\text { and } \\
\text { Evans } \\
1994 \mathrm{p} .\end{array}$ & $\begin{array}{l}\text { Joseph A. } \\
\text { Bellizzi et al, } \\
\text { (1992) }\end{array}$ \\
\hline 8 & $\begin{array}{l}\text { Tata Letak Toko } \\
\text { berpengaruh signifikan } \\
\text { terhadap Kesenangan }\end{array}$ & $\begin{array}{l}\text { Berman } \\
\text { and } \\
\text { Evans } \\
1994 \mathrm{p} .\end{array}$ & $\begin{array}{l}\text { Emmanouela } \\
\text { E. Manganari } \\
\text { et al, }(2011)\end{array}$ \\
\hline 9 & $\begin{array}{l}\text { Tata Letak Toko } \\
\text { berpengaruh signifikan } \\
\text { terhadap Gairah }\end{array}$ & $\begin{array}{l}\text { Berman } \\
\text { and } \\
\text { Evans } \\
1994 \mathrm{p} .\end{array}$ & $\begin{array}{l}\text { Ishwar Kumar } \\
\text { et al, (2010) }\end{array}$ \\
\hline 10 & $\begin{array}{l}\text { Tata Letak Toko } \\
\text { berpengaruh signifikan } \\
\text { terhadap Dominasi }\end{array}$ & $\begin{array}{l}\text { Berman } \\
\text { and } \\
\text { Evans } \\
1994 \mathrm{p} .\end{array}$ & $\begin{array}{l}\text { Fabricio } \\
\text { Rodrigues } \\
\text { Feijo et al, } \\
(2012)\end{array}$ \\
\hline 11 & $\begin{array}{l}\text { Tampilan Bagian } \\
\text { Dalam Toko } \\
\text { berpengaruh signifikan } \\
\text { terhadap Kesenangan }\end{array}$ & $\begin{array}{l}\text { Berman } \\
\text { and } \\
\text { Evans } \\
1994 \mathrm{p} .\end{array}$ & $\begin{array}{l}\text { Jung Min Yoo } \\
\text { et al, (2012) }\end{array}$ \\
\hline 12 & $\begin{array}{l}\text { Tampilan Bagian } \\
\text { Dalam Toko } \\
\text { berpengaruh signifikan } \\
\text { terhadap Gairah }\end{array}$ & $\begin{array}{l}\text { Berman } \\
\text { and } \\
\text { Evans } \\
1994 \mathrm{p} .\end{array}$ & $\begin{array}{l}\text { Jung-Hwan } \\
\text { Kim et al, } \\
(2009)\end{array}$ \\
\hline 13 & $\begin{array}{l}\text { Tampilan Bagian } \\
\text { Dalam Toko } \\
\text { berpengaruh signifikan } \\
\text { terhadap Dominasi }\end{array}$ & $\begin{array}{l}\text { Berman } \\
\text { and } \\
\text { Evans } \\
1994 \mathrm{p} .\end{array}$ & $\begin{array}{l}\text { Feng-Chuan } \\
\text { Pan et al, } \\
(2007)\end{array}$ \\
\hline 14 & $\begin{array}{l}\text { Tampilan Bagian } \\
\text { Dalam Toko } \\
\text { berpengaruh signifikan } \\
\text { terhadap Struktur }\end{array}$ & $\begin{array}{l}\text { Berman } \\
\text { and } \\
\text { Evans } \\
1994 \mathrm{p} .\end{array}$ & $\begin{array}{l}\text { Long-Yi Lin } \\
(2011)\end{array}$ \\
\hline 15 & $\begin{array}{l}\text { Kesenangan } \\
\text { berpengaruh signifikan } \\
\text { terhadap Struktur } \\
\text { Keputusan Membeli }\end{array}$ & $\begin{array}{l}\text { Berman } \\
\text { and } \\
\text { Evans } \\
1994 \mathrm{p} .\end{array}$ & $\begin{array}{l}\text { Julie Baker et } \\
\text { al, (1992) }\end{array}$ \\
\hline 16 & $\begin{array}{l}\text { Gairah berpengaruh } \\
\text { signifikan terhadap } \\
\text { Struktur Keputusan } \\
\text { Membeli }\end{array}$ & $\begin{array}{l}\text { Berman } \\
\text { and } \\
\text { Evans } \\
1994 \mathrm{p} .\end{array}$ & $\begin{array}{l}\text { Grace Yuna } \\
\text { Lee } \text { et al, } \\
(2008)\end{array}$ \\
\hline
\end{tabular}




\begin{tabular}{|c|l|l|l|}
\hline \multirow{3}{*}{17} & Gairah berpengaruh & Berman & Robert J. \\
& signifikan terhadap & and & Donovan et al, \\
& Struktur Keputusan & Evans & (1982) \\
& Membeli & 1994 p. & \\
\hline
\end{tabular}

\section{METODE PENELITIAN}

\section{Jenis Penelitian}

Jenis penelitian yang digunakan dalam penelitian ini adalah penelitian kausalitas (causal analysis), yang bertujuan untuk menganalisis hubungan dan pengaruh sebabakibat antara dua atau lebih variabel, melalui pengujian hipotesis. Paradigma yang digunakan dalam penelitian ini adalah menggunakan metode kuantitatif. Metode ini menekankan pada pengujian teori melalui pengukuran variabel penelitian dengan menggunakan prosedur statistika. Penelitian menggunakan pendekatan deduktif yang bertujuan untuk menguji hipotesis.

\section{Lokasi Penelitian}

Lokasi penelitian adalah minimarket Alfamart, jalan Soekarno Hatta, Ruko Center Point nomer 26-27, Kelurahan Jatimulyo, Kecamatan Lowokwaru, Kota Malang. Latar belakang pemilihan lokasi ini karena pertumbuhan waralaba minimarket ini semakin pesat. Alfamart dipilih karena merupakan perusahaan ritel yang tumbuh pesat nomor dua di Asia. Lokasi jalan Soekarno Hatta merupakan salah satu pusat perniagaan, pemukiman dan pendidikan di Kota Malang, sehingga diharapkan responden dalam penelitian ini dapat lebih heterogen.

\section{Unit Analisis, Populasi, Sampel}

Unit analisis atau responden adalah pengunjung minimarket Alfamart, jalan Soekarno Hatta, Ruko Center Point nomer 2627, Kelurahan Jatimulyo, Kecamatan Lowokwaru, Kota Malang. Populasi adalah seluruh individu yang sudah atau pernah melakukan transaksi pembelian di minimarket Alfamart, yang jumlahnya tidak diketahui. Kriteria sampel dalam penelitian ini adalah pengunjung yang telah melakukan transaksi pembelian di minimarket Alfamart. Teknik pengambilan sampel menggunakan Non Probability Sampling yaitu teknik pengambilan sampel yang memberikan kesempatan yang sama bagi semua unsur dalam populasi untuk dipilih menjadi sampel. Berdasarkan pendapat Hair et al, ukuran jumlah sampel yang diambil dari populasi sebanyak 345 orang. Pengukuran variabel menggunakan skala Likert 5 point, di mana masing-masing pertanyaan diberikan skor 1 sampai 5 Skala Likert (Likert Scale).

\section{HASIL DAN PEMBAHASAN}

Evaluasi Kelayakan Model

Tabel 2. Kelayakan Model

\begin{tabular}{|c|c|}
\hline Variabel & $\mathrm{R}^{2}$ \\
\hline Senang & 0.548 \\
\hline Gairah & 0.384 \\
\hline Dominasi & 0.201 \\
\hline Keputusan & 0.601 \\
\hline
\end{tabular}

Pada model struktural kelayakan model ditunjukkan dari besar $\mathrm{R}^{2}$ model dan composite reliability khusus pada variabel yang memiliki hubungan refleksif dengan indikatornya. Kelayakan model PLS ini dilihat dari nilai $\mathrm{R}^{2}$ model, composite reliability dan Average Variance Extracted (AVE). Pada dua kelayakan yang terakhir dapat terhitung karena sifat hubungan indikator dengan konstruknya adalah refleksif. Pada kedelapan konstruk dihasilkan composite reliabilty berkisar 0,866 - 0,939 dan AVE berkisar 0,501 - 0,762. Ketepatan model secara keseluruhan adalah :

$\mathrm{Q}^{2}$ model $\quad=1-(1-0,548)(1-0,384)(1-$ $0,201)(1-0,601)$

$$
\begin{aligned}
& =1-0,089 \\
& =0,911
\end{aligned}
$$

Tingkat ketepatan model untuk menjelaskan ketiga hubungan konstruk laten adalah $91,1 \%$ sedangkan sisanya dijelaskan oleh konstruk lain yang tidak dilibatkan pada penelitian ini.

\section{Pengujian Inner Model dan Hipotesis Penelitian}

Inner model dievaluasi dengan melihat nilai koefisien jalur hubungan antara variabel laten. Pengujian inner model dilakukan setelah model hubungan yang dibangun sesuai dengan data hasil observasi dan kesesuaian model secara keseluruhan. Tujuan pengujian terhadap inner model adalah untuk mengetahui hubungan antara variabel laten yang ada dalam model hipotesis di penelitian ini.

Uraian hasil pengujian hubungan antara variabel penelitian sebagai berikut : 


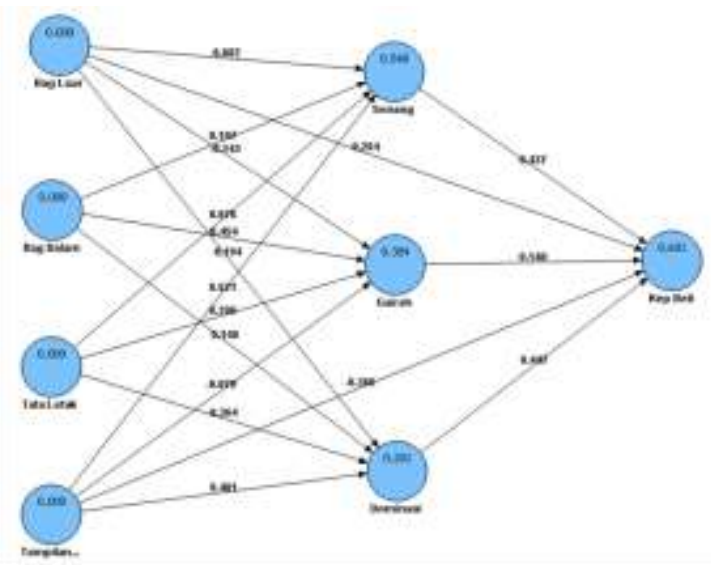

Gambar 3. Inner Model PLS

Hasil pengujian pada Gambar 3 . tampak bahwa terdapat empat persamaan yang menjadi struktur inner model. Bagian Luar Toko, Bagian Dalam Toko, Tata Letak Toko dan Tampilan Bagian Dalam Toko berhubungan langsung dengan Kesenangan, Gairah dan Dominasi. Sedangkan Bagian Luar Toko, Tampilan Bagian Dalam Toko, Kesenangan, Gairah dan Dominasi berhubungan langsung dengan Keputusan Membeli.

Pengujian dari pengaruh langsung antara variabel pada penelitian ini disajikan pada Tabel 14.

\section{Tabel 3. Hasil Uji Inner Model}

\begin{tabular}{|c|c|c|c|c|}
\hline $\begin{array}{l}\text { Hipo } \\
\text { tesis }\end{array}$ & Hubungan & $\begin{array}{c}\text { Original } \\
\text { Sample }(\mathrm{O})\end{array}$ & $\begin{array}{c}\text { Standard } \\
\text { Error } \\
\text { (STERR } \\
\text { ) }\end{array}$ & $\begin{array}{c}\text { T Statistics } \\
(\mid \mathrm{O} / \mathrm{STERR} \\
\mid)\end{array}$ \\
\hline H1 & Bag Luar $->$ Kep Beli & 0.264 & 0.036 & $7.353 *$ \\
\hline $\mathrm{H} 2$ & Bag Luar -> Senang & 0.082 & 0.051 & $1.623 \mathrm{~ns}$ \\
\hline $\mathrm{H} 3$ & Bag Luar $->$ Gairah & -0.143 & 0.046 & $3.116 *$ \\
\hline $\mathrm{H} 4$ & Bag Luar -> Dominasi & 0.194 & 0.042 & $4.593 *$ \\
\hline H5 & Bag Dalam -> Senang & 0.197 & 0.041 & $4.802 *$ \\
\hline H6 & Bag Dalam -> Gairah & 0.454 & 0.043 & $10.494 *$ \\
\hline H7 & $\begin{array}{c}\text { Bag Dalam -> } \\
\text { Dominasi }\end{array}$ & 0.140 & 0.061 & $2.287 *$ \\
\hline $\mathrm{H} 8$ & Tata Letak -> Senang & 0.076 & 0.050 & $1.517 \mathrm{~ns}$ \\
\hline $\mathrm{H} 9$ & Tata Letak -> Gairah & 0.396 & 0.050 & $7.925 *$ \\
\hline $\mathrm{H} 10$ & $\begin{array}{c}\text { Tata Letak -> } \\
\text { Dominasi }\end{array}$ & -0.364 & 0.074 & $4.919 *$ \\
\hline H11 & $\begin{array}{c}\text { Tampilan Dalam -> } \\
\text { Senang }\end{array}$ & 0.521 & 0.054 & $9.712 *$ \\
\hline $\mathrm{H} 12$ & $\begin{array}{c}\text { Tampilan Dalam -> } \\
\text { Gairah }\end{array}$ & -0.070 & 0.048 & $1.477 \mathrm{~ns}$ \\
\hline $\mathrm{H} 13$ & $\begin{array}{c}\text { Tampilan Dalam -> } \\
\text { Dominasi }\end{array}$ & 0.401 & 0.116 & $3.453 *$ \\
\hline $\mathrm{H} 14$ & $\begin{array}{c}\text { Tampilan Dalam -> } \\
\text { Kep Beli }\end{array}$ & -0.365 & 0.059 & $6.220 *$ \\
\hline $\mathrm{H} 15$ & Senang -> Kep Beli & 0.437 & 0.044 & $9.979 *$ \\
\hline H16 & Gairah -> Kep Beli & 0.140 & 0.045 & $3.090 *$ \\
\hline $\mathrm{H} 17$ & Dominasi -> Kep Beli & 0.447 & 0.043 & $10.289 *$ \\
\hline
\end{tabular}

Keterangan $: \mathrm{ns}=$ not significant $; *$

significant pada $\alpha=0.05$ (nilai $\mathrm{t}>1,96$ )

\section{PEMBAHASAN HASIL PENELITIAN}

Berdasarkan hasil penelitian, maka pengujian pengaruh langsung dan hipotesis penelitian bertujuan untuk menjawab apakah hipotesis yang diajukan dapat diterima atau ditolak. Hasil pengujian hipotesis dapat dijelaskan sebagai berikut :

$\mathbf{H}_{1}$ : Hasil pemodelan menerangkan bahwa Struktur Keputusan Membeli ditentukan oleh Desain Bagian Luar Toko. Tampak luar adalah akses awal yang diciptakan toko bagi pembeli. Desain eksterior yang menarik, enak dipandang, pintu masuk yang leluasa serta tempat parkir yang nyaman dan aman akan menciptakan dorongan yang kuat bagi pembeli. Karakteristik eksterior mempunyai pengaruh yang kuat pada keputusan membeli, sehingga harus direncanakan dengan sebaik-baiknya. Kombinasi dari eksterior ini dapat membuat Bagian Luar Toko menjadi terlihat menarik sehingga menimbulkan keinginan orang untuk masuk ke dalam toko.

$\mathbf{H}_{\mathbf{2}}$ : Tingkat Kesenangan pembeli saat melakukan aktifitas berbelanja tidak terjadi di area luar toko. Desain yang menarik pada bagian luar, bagi sebagian pembeli sudah menumbuhkan adanya perasaan senang, akan tetapi tidak pada sebagian lainnya. Perasaan senang akan menguat saat pembeli sudah masuk ke dalam toko dan melihat serta merasakan suasana toko. Rasa senang mengacu pada tingkat di mana individu merasa baik, penuh kegembiraan, bahagia, atau yang berkaitan dengan situasi tersebut.

$\mathbf{H}_{3}$ : Pada hasil pemodelan diperoleh bahwa desain Bagian Luar Toko dengan desain yang terlampau menarik akan menurunkan Gairah pembeli. Penelitian ini mendukung teori yang dikemukakan oleh Berman and Evans (1994 h. 554-561), Bagian Luar Toko salah satunya adalah marquee (simbol/logo) yang mempunyai pengaruh terhadap reputasi sebuah toko, sehingga harus diupayakan tampil lebih menarik dan mencolok dibanding dengan lingkungan sekitarnya.

$\mathbf{H}_{4}$ : Bagian Luar Toko dapat terukur dari penilaian pembeli terhadap desain bagian muka, logo toko, akses pintu masuk, tampilan produk yang tertata rapi, ukuran gedung, tingkat keramaian pengunjung dan tempat parkir. Karakteristik eksterior mempunyai pengaruh yang kuat pada citra toko tersebut, sehingga harus direncanakan dengan sebaik mungkin. Kombinasi dari eksterior ini dapat membuat Bagian Luar Toko menjadi terlihat menarik 
sehingga mengundang orang untuk masuk ke dalam toko. Pada hasil penelitian ini bagian luar toko adalah faktor pendorong yang nyata dalam meningkatkan dominasi pembeli.

$\mathbf{H}_{5}$ : Peranan Bagian Dalam Toko adalah penting dalam meningkatkan Kesenangan pembeli. Desain interior dari suatu toko harus dirancang untuk memaksimalkan visual merchandising. Display yang baik yaitu yang dapat menarik perhatian pengunjung dan membantu mereka agar mudah mengamati, memeriksa dan memilih barang dan akhirnya melakukan pembelian. Banyak hal yang akan mempengaruhi persepsi konsumen pada toko tersebut.

$\mathbf{H}_{6}$ : Bagian Dalam Toko bersama Bagian Luar Toko dan Tata Letak adalah tiga faktor penting bagi Gairah pembeli, hanya saja pada Bagian Luar Toko mempunyai sifat yang berlawanan dengan dua penentu lainnya. Konsumen yang berkunjung akan tertarik pada sesuatu yang paling terang yang berada dalam pandangan mereka. Tata cahaya yang baik mempunyai kualitas dan warna yang dapat membuat suasana yang ditawarkan terlihat akan lebih menarik, terlihat berbeda bila dibandingkan dengan keadaan yang sebenarnya.

$\mathbf{H}_{7}$ : Dominasi pembeli dijelaskan secara signifikan oleh empat variabel yaitu Bagian Luar Toko, Bagian Dalam Toko dan Tampilan Bagian Dalam dengan arah positif serta Tata Letak dengan arah negatif. Berdasarkan koefisien jalur yang terhitung dari model PLS kontribusi yang paling kuat bersumber dari Tampilan Bagian Dalam. Secara khusus pada Bagian Dalam peranan terhadap Dominasi pembeli lebih banyak dijelaskan oleh kemudahan dalam menjangkau produk, pemutaran musik, warna cat yang enak dipandang dan pelayanan yang ramah.

$\mathbf{H}_{8}$ : Tata Letak Toko mempunyai peranan penting dalam menumbuhkan Gairah dan menekan Dominasi, akan tetapi tidak berkontribusi besar untuk meningkatkan Kesenangan. Tingkat Kesenangan pembeli tidak banyak dijelaskan oleh Tata Letak. Bagi sebagian pembeli Tata Letak akan meningkatkan rasa senang saat berbelanja. Pengelola toko harus mempunyai rencana dan memanfaatkan ruangan toko yang ada seefektif mungkin.

H9 : Tata Letak Toko berkontribusi besar untuk meningkatkan Gairah pembeli. Penataan yang ada di dalam toko meliputi ruangan penjualan, ruangan pegawai, ruangan pelanggan dan arus lalu lalang. Pengelola toko harus mempunyai rencana dalam penentuan lokasi dan fasilitas toko. Pengelola toko juga harus memanfaatkan ruangan toko yang ada seefektif mungkin. Rancangan penataan yang tepat akan menumbuhkan Gairah baru bagi pembeli untuk memilih dan mencermati barang yang hendak dibeli. Bahkan konsep penataan yang baik bisa berpotensi untuk merangsang pembeli melihat barang-barang lain yang sebenarnya tidak sedang berada dalam daftar rencana beli.

$\mathbf{H}_{10}$ : Peranan Tata Letak terhadap Dominasi adalah berbeda bila dibandingkan dengan Gairah. Tata Letak berpengaruh positif terhadap Gairah akan tetapi berpengaruh negatif terhadap Dominasi. Dominasi pembeli menjadi tergeser oleh pihak toko, karena Tata Letak yang baik mengakibatkan kontrol lebih banyak dikendalikan oleh toko. Salah satu bagian Tata Letak yang penting adalah arus lalu-lalang. Dalam hal ini jarak antar rak perlu diperhatikan agar konsumen dapat berlalu-lalang dengan bebas dan lancar.

$\mathbf{H}_{11}$ : Tampilan Bagian Dalam akan menyesuaikan dengan kebutuhan tertentu sesuai dengan waktu dan suasana yang ada saat itu, seperti Hari Raya Agama (Lebaran, Natal, Imlek), hari Kemerdekaan atau hari ulang tahun toko. Toko pada Bagian Dalam akan di desain sesuai dengan tema-tema tersebut. Perubahan tampilan dalam toko akan menaikkan rasa senang pembeli, karena di dalam toko menghadirkan suasana baru di saat itu.

$\mathbf{H}_{12}$ : Salah satu bentuk Tampilan Bagian Dalam Toko adalah dalam satu musim tertentu toko dapat menampilkan dekorasi baru yang sesuai dengan tema tertentu, termasuk baju yang dikenakan oleh pekerja dalam toko. Akan tetapi dari hasil pemodelan, perubahan tampilan ini tidak berkontribusi besar terhadap Gairah pembeli. Interior Displays yang sangat berpengaruh adalah Dekorasi Ruangan. Dekorasi Ruangan pada dinding bisa merupakan kombinasi dari gambar atau poster yang ditempel, warna pada dinding dan sebagainya yang dapat meningkatkan kemeriahan suasana toko.

$\mathbf{H}_{13}$ : Tampilan Bagian Dalam Toko berkontribusi kuat terhadap Dominasi pembeli. Suasana baru dalam toko merangsang pembeli untuk lebih bebas mengamati dan mencermati isi toko. Perubahan suasana tampilan dalam toko juga akan diikuti dengan adanya produk- 
produk tertentu yang hanya disediakan pada saat itu. Bagian Interior Displays yang juga berpengaruh adalah seragam pegawai. Model seragam pegawai dapat berfungsi sebagai penarik minat konsumen untuk berbelanja. Pada waktu-waktu tertentu, seragam pegawai dapat disesuaikan dengan tema-tema tertentu pula.

$\mathbf{H}_{14}$ : Tampilan Bagian Dalam Toko berpengaruh terhadap Struktur Keputusan Membeli. Keputusan Membeli mengalami peningkatan pada saat musim tertentu yang berkaitan dengan hari besar keagamaan atau hari libur besar lainnya. Kenaikan keputusan pembelian ini terjadi dengan beberapa alasan penunjang seperti adanya penambahan dekorasi ruangan / visual merchadising maupun penataan display yang disesuaikan dengan tema tertentu tersebut. Secara keseluruhan, Interior Displays terdiri dari Dekorasi Sesuai Tema, Seragam Pegawai, dan Dekorasi Ruangan. Apabila ketiga hal ini dapat diterapkan secara efektif, maka akan dapat mendorong konsumen untuk melakukan keputusan pembelian.

$\mathbf{H}_{15}$ : Menciptakan rasa senang bagi pembeli adalah penting karena dapat meningkatkan keputusan membeli. Hasil penelitian ini menunjukkan bahwa Kesenangan dalam Emosi terutama yang berhubungan dengan ketulusan, kualitas dan keterpenuhan atas harapan akan mendorong pembeli untuk memilih produk bermerek dan akan membeli sesuai dengan jumlah yang diperlukan.

$\mathbf{H}_{16}$ : Gairah pembeli bisa tergambarkan dari berbagai sikap pembeli seperti aktif memperhatikan produk-produk yang dijual, tidak mempunyai perasaan bosan dalam berbelanja dan didukung oleh karyawan toko yang selalu memberikan pelayanan prima bagi pembeli. Penurunan Gairah pembeli juga akan menurunkan Struktur Keputusan Membeli, sehingga menciptakan suasana yang menimbulkan Gairah tinggi adalah hal yang penting bagi toko.

$\mathbf{H}_{17}$ : Konstribusi Dominasi terhadap Struktur Keputusan Membeli adalah paling kuat. Hal ini tampak dari koefisien jalur yang bernilai paling besar dibandingkan dengan empat variabel penentu lain terhadap Struktur Keputusan Membeli. Ciri utama dari Dominasi yang bisa dimiliki pembeli adalah timbulnya rasa enjoy saat melakukan aktifitas berbelanja.

\section{KESIMPULANDAN SARAN Kesimpulan}

Berdasarkan hasil analisis pemodelan dengan Partial Least Square dan pembahasan terhadap seluruh hipotesis yang ada dalam model penelitian, maka didapatkan beberapa kesimpulan sebagai berikut :

1. Bagian Luar Toko berpengaruh signifikan terhadap variabel Struktur Keputusan Membeli.

2. Bagian Luar Toko berpengaruh tidak signifikan terhadap variabel Kesenangan.

3. Bagian Luar Toko berpengaruh signifikan terhadap variabel Gairah.

4. Bagian Luar Toko berpengaruh signifikan terhadap variabel Dominasi.

5. Bagian Dalam Toko berpengaruh signifikan terhadap variabel Kesenangan.

6. Bagian Dalam Toko berpengaruh signifikan terhadap variabel Gairah.

7. Bagian Dalam Toko berpengaruh signifikan terhadap variabel Dominasi.

8. Tata Letak Toko berpengaruh tidak signifikan terhadap variabel Kesenangan.

9. Tata Letak Toko berpengaruh signifikan terhadap variabel Gairah.

10. Tata Letak Toko berpengaruh signifikan terhadap variabel Dominasi.

11. Tampilan Bagian Dalam Toko berpengaruh signifikan terhadap variabel Kesenangan.

12. Tampilan Bagian Dalam Toko berpengaruh tidak signifikan terhadap variabel Gairah.

13. Tampilan Bagian Dalam Toko berpengaruh signifikan terhadap variabel Dominasi.

14. Tampilan Bagian Dalam Toko berpengaruh signifikan terhadap Struktur Keputusan Membeli.

15. Kesenangan berpengaruh signifikan terhadap variabel Struktur Keputusan Membeli.

16. Gairah berpengaruh signifikan terhadap variabel Struktur Keputusan Membeli.

17. Dominasi berpengaruh signifikan terhadap variabel Struktur Keputusan Membeli.

\section{Saran}

Hasil penelitian ini akan memberikan beberapa saran penting terhadap dua aspek yaitu aspek teori dan praktis sebagai berikut :

1. Ditinjau dari aspek teoritis, penelitian ini dapat memberikan sumbangsih pengetahuan tentang perilaku konsumen yang berkaitan dengan perilaku membeli di toko. 
2. Penelitian ini memungkinkan bagi pengembangan dan pengujian ulang model penelitian dengan penambahan variabel baru.

3. Penelitian yang akan datang diharapakan dapat mengembangkan konseptual dan pemodelan pada objek-objek kajian penelitian yang lebih luas, sehingga dapat diperoleh perbandingan tentang hasil-hasil riset yang telah dilakukan.

4. Ditinjau dari sisi aspek praktis, penelitian ini diharapkan dapat digunakan sebagai bahan pertimbangan guna menerapkan kebijakan perusahaan khususnya yang berorientasi pada kepentingan konsumen. Pihak toko lebih memprioritaskan tumbuhnya rasa senang dan dominasi pembeli melalui rancangan tampilan dalam toko, bagian luar dan tata letak.

\section{DAFTAR PUSTAKA}

Arikunto, Suharsimi. 2006. Prosedur Penelitian Suatu Pendekatan Praktik. Penerbit Rineka Cipta. Jakarta.

Berman, Barry and Evans, Joel R. 1994. Marketing Sixth Edition. Macmillan Publishing Company. New York.

2002. Retail Management: a Strategic Approach. Fifth Edition. Macmillan Publishing Company. New York.

Chen, Han-Shen. Hsieh Tsuifang. 2010. "The Effect of Atmosphere on Customer Perception and Customer Behaviour Responses in Chain Store Supermarket: African Journal of Business Management 5 (24): $10054-10066$.

Donovan, J Robert. Rossiter, John R. 1982. "Store Atmosphere: An Environmental Psychology Approach: Journal of Retailing: 58 (1): 34 - 57.

Effendi, Sofian. Tukiran (Ed). 2012. Metode Penelitian Survai. Cetakan ke Tiga Puluh. Penerbit LP3ES. Jakarta.

Eroglu, Sevgin A. Machleit, Karen A. Davis, Lenita M. 2003. "Empirical Testing of a Model of Online Store Atmospherics and Shopper Responses: Journal of Psychology and Marketing: Wiley Periodicals: 20 (2): $139-150$.
Feijo, Fabricio Rodrigues. Botelho, Delane. 2012. "The Effect of Factors Related to Merchandising on Retail Sales: RAE: 52 (6): $628-642$.

Foster, Bob. 2008. Manajemen Ritel. Penerbit Alfabeta. Bandung.

Hair, Joseph F. Black, William C. Babin, Barry J. Anderson, Rolph E. Tatham, Ronald L. 2006. Multivariate Data Analysis. Sixth Edition. Pearson Prentice Hall. New Jersey.

Hawkins, Dell. Mothersbaugh David. 2013. Consumer Behaviour: Building Marketing Strategy. Twelfth Edition. Mc Graw Hill. New York.

Kim, Hye-Jong. Lennon Sharon J. 2010. "Eatmosphere, Emotional, Cognitive, and Behavioral Responses: Journal of Fashion Marketing and Management: Emerald Group Publishing: 14 (3): 412 - 428.

Kim, Jung-Hwan. Kim, Min-Jeong. Lennon, Sharron J. 2009. "Effect of Website Atmospherics on Consumer Responses Music and Product Presentation: Direct Marketing: International Journal: Emerald Group Publishing: 3 (1): $4-19$.

Kotler, Philip dan Gary, Armstrong. 2008 a. Prinsip-prinsip Pemasaran. Terjemah oleh Bob Sabran. Jilid Satu. Edisi Keduabelas. Penerbit Erlangga. Jakarta.

2008 b. Prinsip-prinsip Pemasaran. Terjemah oleh Bob Sabran. Jilid Dua. Edisi Keduabelas. Penerbit Erlangga. Jakarta.

Kumar, Ishwar. Garg, Ruchi. Rahman, Zillur. 2010. "Influence of Retail Atmospherics on Customer Value in an Emerging Market Condition: Journal Marketing: Great Lakes Herald: 4 (1): 1 - 13.

Laroche, Michel. Teng, Lefa. Michon, Richard. Chebat, Jean C. 2005. "Incorporating Service Quality Into Consumer Mall Shopping Decision Making: a Comparison Between English and French Canadian Consumers: Journal of Services Marketing: Emerald Group Publishing: 19 (13): 157 163.

Lee, Grace Yuna. Yi, You-Jae. 2008. "The Effect of Shopping Emotions and Perceived Risk on Impulsive Buying: The Moderating 
Role of Buying Impulsiveness Trait: Seoul Journal of Business: 14 (2): 67 - 92.

Levy Michael and Weitz A. Barton. 2004. Retailing Management. Fifth Edition. McGraw Hill International Edition. Singapore.

Lin, Ingrid Y. 2008. "The Interactive Effect of Gestalt Situation and Arousal Seeking Tendency on Customers Emotional Responses: Matching Color and Music to Specific Servicescapes: Journal of Services Marketing: 24 (4): 294 - 304.

Manganari, Emmanouela E. Rigopoulou, Irini D. Siomkos, George J. Vrechopoulos, Adam P. 2011. "Virtual Store Layout Effects on Consumer Behaviour: Applying an Environmental Psychology Approach in The Online Travel Industry: Internet Research Journal: Emerald Group Publishing: 21 (3): 326 - 346.

Mehrabian, A. 1976. Public Spaces and Private Spaces: The Psychology of Work, Play and Living Environments. Basic Books Inc. New York.

Pan, Feng-Chuan. Su, Suh-Jean. Chiang, CheChao. 2007. " Dual Attractiveness of Winery: Atmospheric Cues on Purchasing: International Journal of Wine Business Research: Emerald Group Publishing: 20 (2): $95-110$.

Penz, Elfriede. Hogg, Margaret K. 2009. "The Role of Mixed Emotions in Consumer Behaviour: Investigating Ambivalence in Consumers Experiences of Approach Avoidance Conflicts in Online and Offline Settings: European Journal of Marketing: Emerald Group Publishing 45 (12): 104 132.

Peter, J Paul dan Jerry, C Olson. 2000. Consumer Behaviour: Perilaku Konsumen dan Strategi Pemasaran. Terjemahan Damos Sihombing. Jilid Dua. Edisi Empat. Penerbit Erlangga. Jakarta.

Sekaran, Uma. 2006. Research Methods for Business: Metodologi Penelitian untuk Bisnis. Terjemah oleh Kwan Men Yon. Buku Dua. Edisi Empat. Penerbit Salemba Empat. Jakarta.

2007. Research Methods for Business: Metodologi Penelitian untuk
Bisnis. Terjemah oleh Kwan Men Yon. Buku Satu. Edisi Empat. Penerbit Salemba Empat. Jakarta.

Sheng, Jiun. Lin, Chris. Yi, Liang-Haw. 2011. "The Influence of Service Environments on Customer Emotion and Service Outcomes: Management Service Quality Journal: Emerald Group Publishing: 21 (4): 350 372.

Singarimbun, Masri. Effendi, Sofian. Tukiran (Ed). 2012. Metode Penelitian Survai. Penerbit LP3ES. Jakarta.

Solimun. 2007. Analisis Multivariat Pemodelan Struktural : Metode Partial Least Square PLS. CV Citra. Malang.

Turley, L W and Milliman Ronald, E. 2000. "Atmospheric Effects on Shopping Behavior: a Review of The Experimental Evidence: Journal of Business Research. Elsevier Science Inc. 49: 193 - 211.

Utami, Christina Whidya. 2010. Manajemen Ritel: $\quad$ Strategi dan Implementasi Operasional Bisnis Ritel Modern di Indonesia. Edisi 2. Penerbit Salemba Empat. Jakarta.

Wu, Paul CS. Gary, Yeong-YuhYeh. Hsiao, Chieh-Ru. 2011. "The Effect of Store Image and Service Quality on Brand Image and Purchase Intention for Private Label Brand: Australasian Marketing Journal: 19 (1): $30-39$.

$\mathrm{Xu}$, Ying-Jiao. 2007. "Impact of Store Environment on Adult Generation Y Consumers Impulse Buying: Journal of Shopping Center Research: 14 (1): 39 - 56.

Yoo, Jung-Min. Kim, Min-Jeong. 2012. "Online Product Presentation: The Effect of Product Coordination and a Models Face: Journal of Research in Interactive Marketing: Emerald Group Publishing: 6 (1): $59-72$.

Young, Ha. Im, Hyun-Joo. 2011. "Role of Web Site Design Quality in Satisfaction and Word of Mouth Generation: Journal of Service Management: 23 (1): 79 - 96. 